\title{
First record of two species of the genus Junonia (Nymphalidae: Lepidoptera) from Sanghar, Sindh
}

\author{
Bhojoo Mal*, Nasreen Memon, Shakeel Ahmed Memon, Mansoor Ali \\ Shah and Nadir Ali Shah \\ Department of Zoology University of Sindh, Jamshoro, Sindh, Pakistan \\ *Corresponding author's email: bhojumal@yahoo.com \\ Citation \\ Bhojoo Mal* Nasreen Memon, Shakeel Ahmed Memon, Mansoor Ali Shah and Nadir Ali Shah. First record of two \\ species of the genus Junonia (Nymphalidae: Lepidoptera) from Sanghar, Sindh. Pure and Applied Biology. Vol. 4, \\ Issue 4, 2015, pp 522-527. http://dx.doi.org/10.19045/bspab.2015.44010
}

Received: 05/08/2015

Revised: 05/11/2015

Accepted: $14 / 11 / 2015$

\section{Abstract}

The genus Junonia belonging to family Nymphalidae. The butterflies of the Nymphalidae commonly called brush-footed butterflies, because the fore legs are reduced in both sexes. They are very beautiful and attractive due to their multicolored wings. The specimens of Junonia were collected from the different localities of Sanghar, Sindh. Two species of the genus Junonia namely Junonia lemonias Linnaeus and Junonia orithya Linnaeus were identified. These species are described here on the basis of morphological characters body color and internal male and female genitalia. These species are the first time record from Sanghar, Sindh.

Key words: Junonia lemonias L.; Junonia orithya L.; First record; Sanghar; Sindh.

\section{Introduction}

The genus Junonia belonging to the family Nymphalidae. The butterflies of the genus Junonia are medium sized butterflies, commonly called Pansies. This group is widely distributed and known as "Brushfooted Butterflies" because fore legs of the males and females are reduced and covered with hair, these legs they do not use for walk but use as sensory organ, only middle and hind legs are well developed, used for walking [1]. The inner margin of the hind wings has concave channels, which covered the abdomen when they sit. The species of genus Junonia have bright colour with eye shaped ocelli, which they use in defense. The species of this genus are fly for a long distance and carry pollens which help in the cross pollination [2]. In the world about thirty-three species of Junonia are reported, out these six species have been recorded from Pakistan [3]. Presently, two species of the genus Junonia namely Junonia lemonias Linnaeus, 1758 and Junonia orithya Linnaeus, 1758 were identified from the Sanghar, Sindh, Pakistan.

\section{Materials and Methods}

The specimens of genus Junonia were collected during January 2015 to May 2015 from crops, fruits, vegetables and gardens of different localities of Sanghar, Sindh. The collected specimens were brought to Entomology laboratory, department of Zoology, University of Sindh, Jamshoro. The butterflies were killed by putting into the Refrigerator for the overnight. The 
specimens were stretched on the stretching board and kept for 24 hours. After that, these specimens were preserved in the insect wooden boxes; naphthalene balls were put in the box to protect them from the predator and fungus. The identification was done under dissected binocular microscope with the key given by Hampson [4] and wing venation of Miller [5]. For the dissection of the male and female genitalia, the abdomen of the species of Junonia separated from the rest of body, boiled into $10 \%$ of potassium hydroxide $(\mathrm{KOH})$. Then the abdomen dissected from the lateral side under the binocular microscope, the genitalia of the male and female removed from the abdomen with the help of fine forceps, washed with the tap water and preserved into the glycerin and attached with the specimen $[6,7]$. Genital terminology was used as suggested by Klots [8] and Winter [9].

\section{Results}

\section{Junonia lemonias L., 1758}

(Lemon pansy) (Figure A1 and B1)

\section{Coloration}

Head, eyes and antennae dark brown, maxillary palpi pale dull ochraceous, proboscis black; thorax dark brown, fore wings dark brown with lemon yellow eye spots and lines, ocelli shaded with red and black, hind wings dark brown, terminal margin with light yellowish bands, ocelli shaded with red and black; abdomen dark brown.

\section{Structure}

\section{Head}

Head round, frons broad, convex, eyes large, antennae half of the length of the wings, apical part spoon shaped, maxillary palpi porect anteriorly, second segment large, proboscis large, highly coiled.

\section{Thorax}

Thorax broad densely covered with hair, legs covered with white scales and spines.

Fore wings (Figure $\mathrm{C} 1$ )
Large than hind wing, costa largely arched, apex angular, termen concave at middle, tornus rounded, dorsum straight, discoidal cell opened; veins, Sc originated from axillary region reach to the length of discal cell, R1 arised from the base of the wing, forked into R2 and further into R3, R4 and $\mathrm{R} 5, \mathrm{R} 2$ anastomosing with $\mathrm{R} 3$ and ending before the apex of wing, R3 ending at the apex, R4 and R5 ending at the termen, M1 originated from the upper angle of the discal cell, M2 originated from the below of the upper angle, M3 anastomosing with $\mathrm{Cu} 1$ originated from the lower angle of the discal cell, $\mathrm{Cu} 2$ parallel with $\mathrm{Cu} 1, \mathrm{~A}_{2}$ arised from the axillary region, separately from the distal cell up to the tornus of the wing.

Hind wings (Figure D1)

Leaf shaped, costa arched at base, apex sub round, termen sinuated, tornus pointed, dorsum curved, discoidal cell opened; veins, $\mathrm{Sc}+\mathrm{R} 1$ arised from the axillary region, short and separated from R1, humeral (h) curved toward the proximal region of the costal margin began from $\mathrm{Sc}+\mathrm{R} 1$ and $\mathrm{Rs}$, Rs ending at the termen, M1 originated from upper angle of the discal cell, M2 originated from lower side of the upper angle of the discal cell, M3 anastomosing with $\mathrm{Cu}$ loriginated from lower angle of the cell, $\mathrm{Cu} 1$ and $\mathrm{Cu} 2$ began separately from the discal cell for an unequal distance reaching at the termen, $\mathrm{A} 2$ and $\mathrm{A} 3$ originate from the axillary of the wing began separately then meet again at the middle of the dorsum.

Male genitalia (Figure E1 and F1)

Symmetrical, uncus sclerotised, sickle shaped in lateral view, dorsally tapered towards apex, tegumen broad anteriorly, narrow posteriorly, vinculum short, saccus V-shaped, lateral margin without saccular process, juxta angular, valvae, anteriorly broad, posteriorly narrow with hair, aedeagus sclerotised (Figure G1), dorsally straight, ventrally curved. 

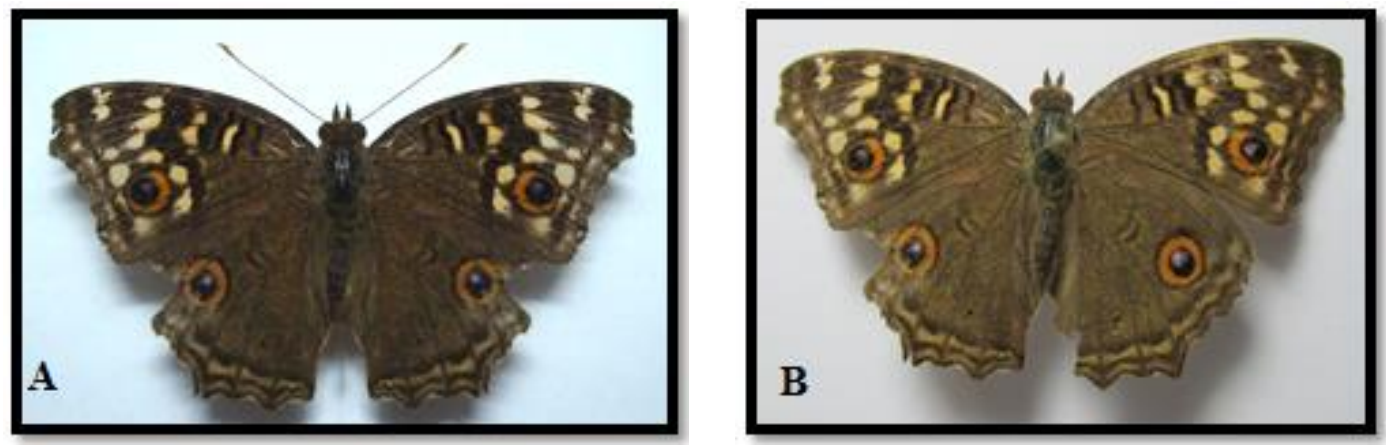

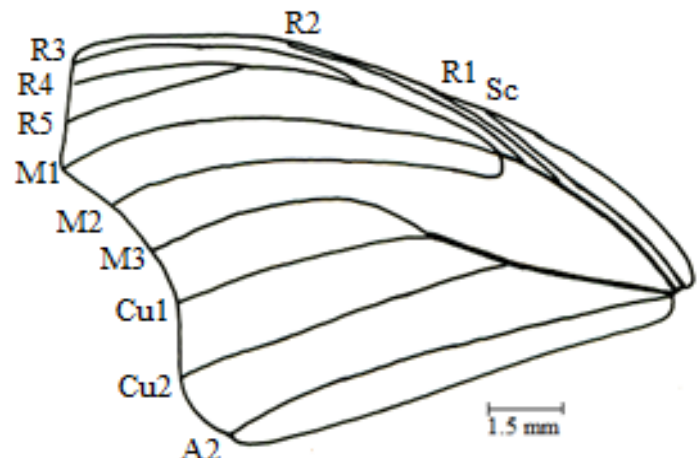

Fig. C

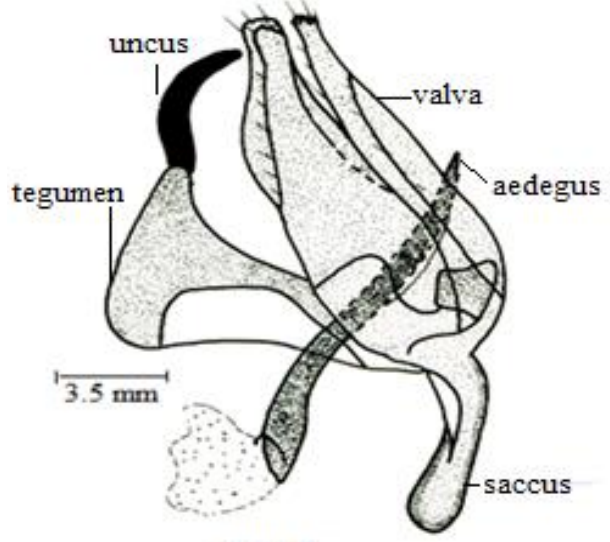

Fig. E

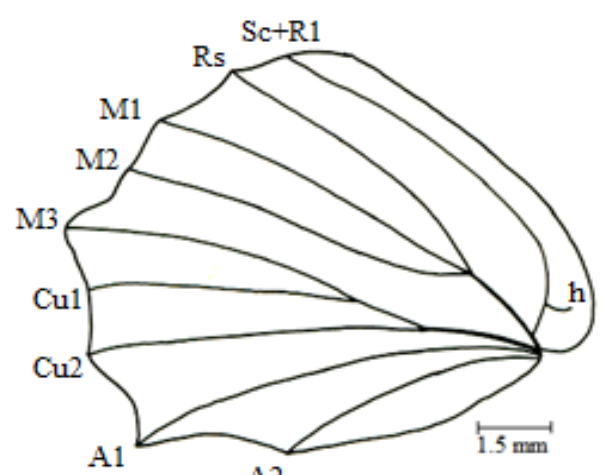

Fig. D

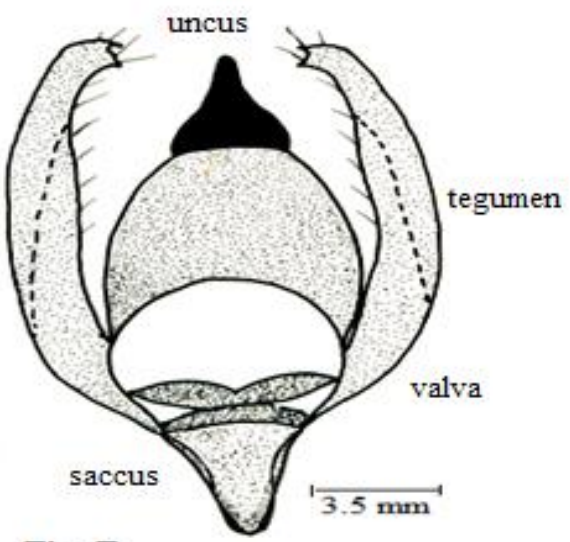

Fig. F

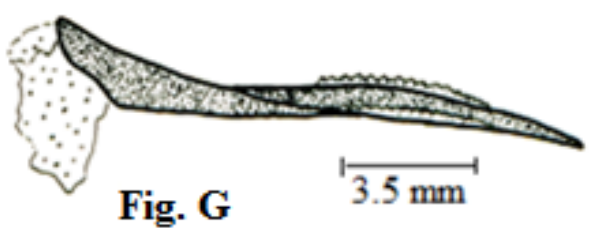

Figure 1. Junonia lemonias L. A. Male; B. Female; C. Fore wing; D. Hind wing; E. Male genitalia (Lateral side); F. Male genitalia (dorsal side); G, Aedeagus. 
Junonia orithya L., 1758

(Blue pansy) (Figure A2 and B2)

\section{Coloration}

Head reddish-brown, eyes and antennae brown, palpi dull white, proboscis light brown; thorax, dorsally black, ventrally dull white, legs dull white, fore wings, ground colour velvety black, apical half of the wing dull fuliginous, two short orange bars in discal area, one black eye spot ringed with orange yellow in interspace 3, sub-terminal line spots in interspaces, Hind wings, ground colour black with blue shaded scales, a white centered orange spot ringed with black in postdiscal interspace 2, around small white centered velvety black spot in interspace 5, terminal narrowly white; abdomen, dorsally black, ventrally dull white.

\section{Structure}

\section{Head}

Head round, frons broad, convex, eyes large (Figure C2), antennae half of the length of the wings, apical part spoon shaped, palpi porect anteriorly, first and third segments short, proboscis large, highly coiled.

Fore wings (Figure D2)

Triangular, slightly longer than hind wing, costa widely arched; apex sub-round, termen slightly sinuated, tornus angular, dorsum slightly sinuated, discoidal cell opened; veins, Sc (Subcosta) arised from the axillary of the wing, ending at the middle of the costal margin, $\mathrm{R}$ (Radial) arised next and parallel to Sc, at distally forks into R1 and Rs, later being divided into R2, R3, R4 and $\mathrm{R} 5, \mathrm{R} 2$ ending before the apex of the wing, R4 and R5 largely stalked, forks from R3, anastomosing with M1and starts from the upper angle of the discal cell, , R3 and R4 ending at the apex of the wing, R5 ending on the terminal margin, M1 began from upper angle of discal cell, M2 began from lower side of upper angle of the discal cell, M3 began from lower angle of the discal cell, $\mathrm{Cu} 1$ starts from lower angle of the discal cell, Cu2 starts from the discal cell, parallel to $\mathrm{Cu} 2$, ending at the terminal margin of the wing and $\mathrm{Cu} 2$ began separately from discal cell for an unequal distance, A2 arised from the axillary region, separately from the distal cell up to the tornus of the wing.

Hind wings (Figure E2)

Leaf shaped, costa sinuated, apex subrounded, termen sinuated, tornus angular, dorsum sinuated, discoidal cell opened, Sc+ $\mathrm{R} 1$ arised from the axillary region, ending middle of the costal margin, humeral (h) curved toward the proximal region of the costal margin began from $\mathrm{Sc}+\mathrm{R} 1$, Rs end separates from $\mathrm{Sc}+\mathrm{R} 1$, ending at the apex of the wing, M1 and M2 began from upper angle of the discal cell, M3 starts from lower angle of the discal cell, Cu1 began from the lower angle of the discal cell, $\mathrm{Cu} 2$ starts from the discal cell, parallel to $\mathrm{Cu}$, two veins $\mathrm{A} 2$ and $\mathrm{A} 3$ arise from the axillary of the wing respectively, A2 ending at the tornus of wing, $\mathrm{A} 3$ ending at dorsal margin. Male genitalia (Figure F2 and G2)

Symmetrical, uncus sclerotised, curved downward in lateral view, ventrally pointed toward apex, tegumen sclerotised, laterally broad, gradually narrowed posteriorly, ventrally broad, appendices reduced, vinculum larger than the tegumen, laterally curved inward, fultura inferior reduced, saccus sclerotised, rod-like, U-shaped in dorsal view, valva elongated, costa margin curved inward laterally without hair, apex sub-rounded with sinuated process in lateral view, ventral margin convex without hair, aedeagus sclerotised (Figure H2), ventrally curved, apex pointed, conjunctival membrane present.

Female genitalia (Figure I2)

Papillae anales somewhat round, covered with hair, apophysis posterior long, rod-like, apophysis anterior long, thorn-like, ductus bursae short, tube-like, corpus bursae balloon like without cornuti. 

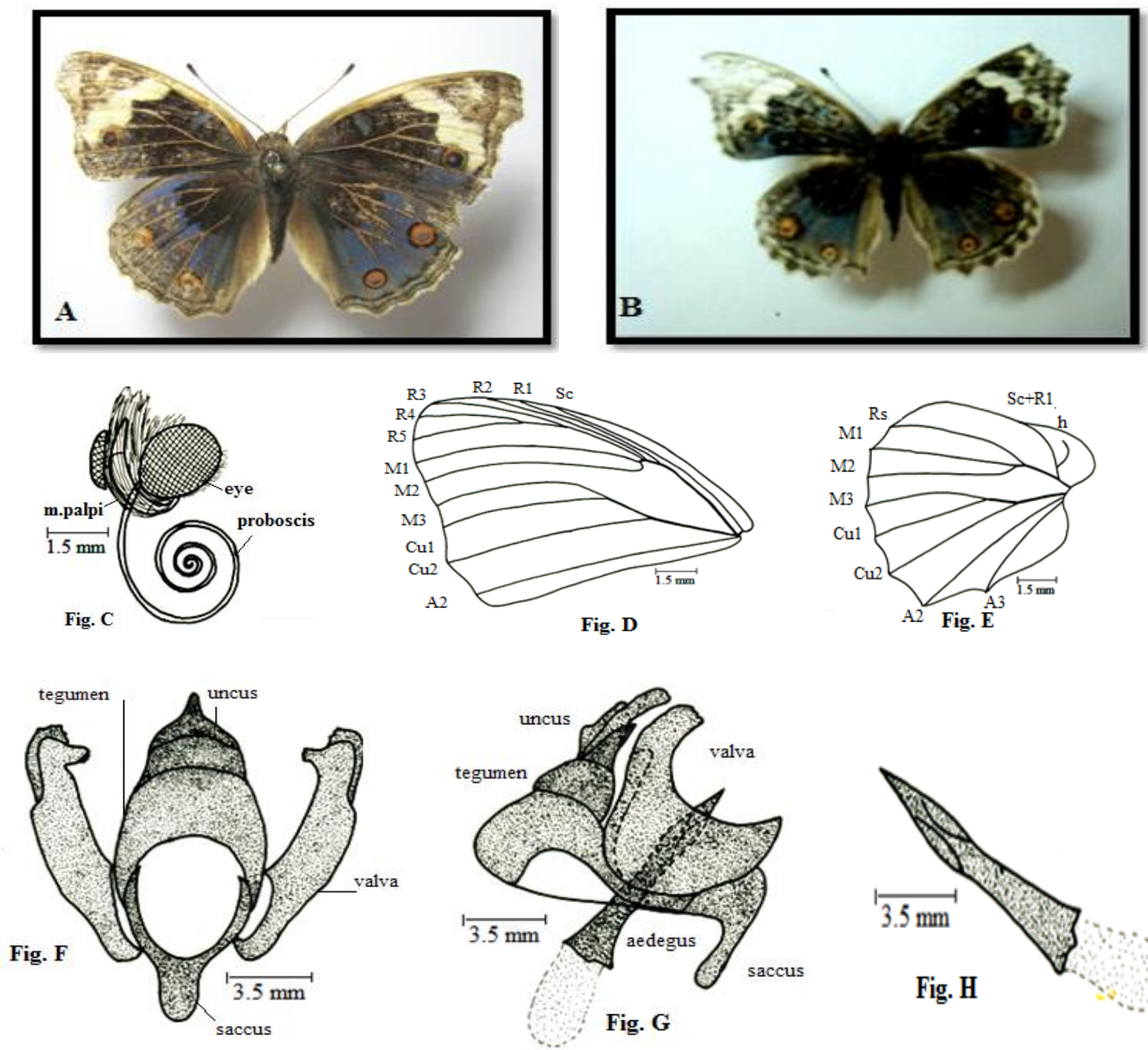

Fig. G
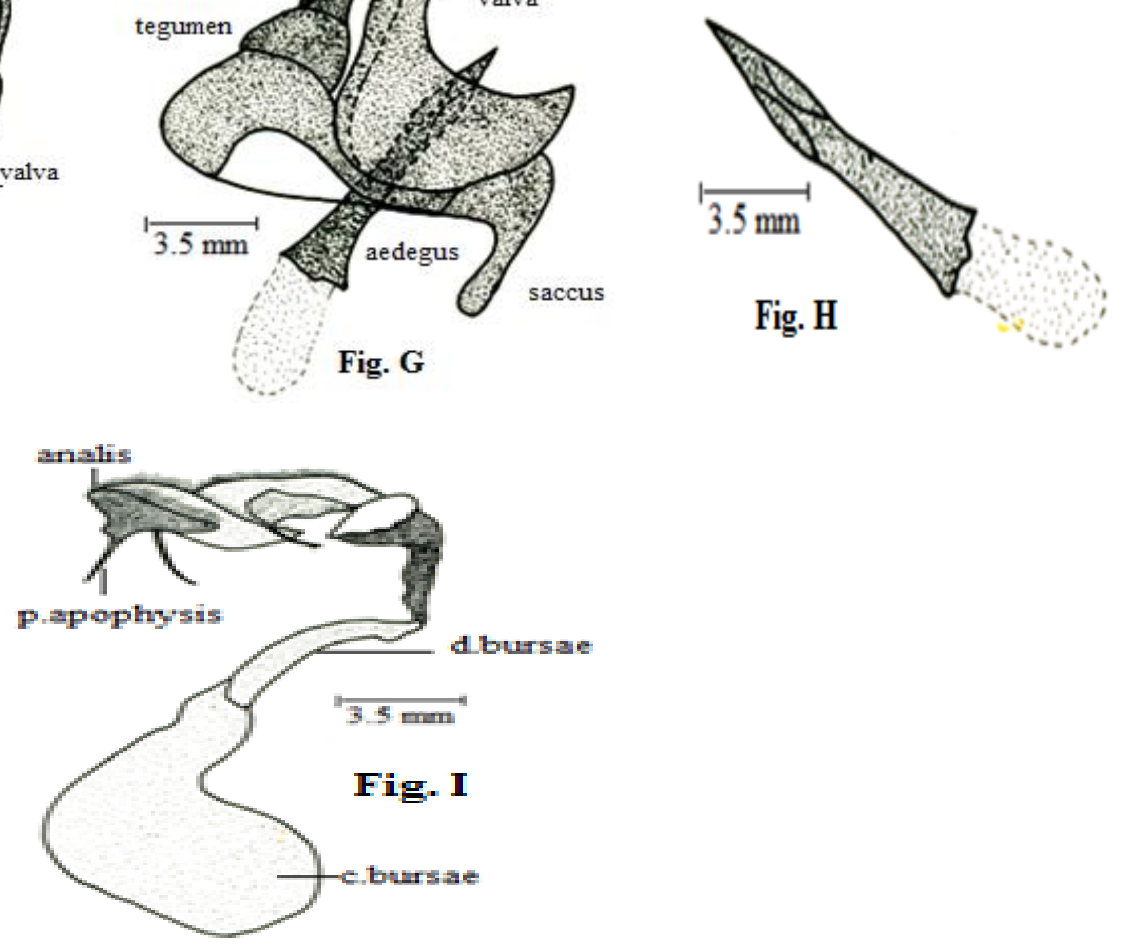

Figure 2. Junonia orithya L. A. Male; B. Female; C. Eye; D. Fore wing; E. Hind wing; F. Male genitalia (Dorsal side); G. Male genitalia (Lateral side); H, Aedeagus; I. Female genitalia. 


\section{Discussion}

The butterflies of the genus Junonia have been recorded from Pakistan by many scientists such as Lesilie and Evans reported from Chitral [10]; Bingham from British India [11]; Puri from different localities of Pakistan [12]; Ahsan and Iqbal from the Lahore [13]; Arshad et al. from Khyber Pakhtunkhwa (KPK) [14]; Roberts from different localities of Pakistan [15]; Khan et al. from Azad Kashmir [16]. Previously, scholars worked on the genus Junonia from the different localities of Pakistan, but from Sindh very little work has been done on the genus Junonia. They described the species of Junonia on the basis of morphological characters. Presently, two species of the genus Junonia namely Junonia lemonias Linnaeus, 1758andJunonia orithya Linnaeus, 1758were documented for the first time from Sanghar, Sindh. These species are described here on the basis of the morphological characters, body colour and internal male and female genitalia. This study will help understanding the species of the genus Junonia.

\section{Authors' contributions}

Conceived and designed the experiments: B Mal \& N Memon. Performed the experiments: B Mal. Analyzed the data: SA Memon. Contributed reagents/ materials/ analysis tools: B Mal, MA Shah, NA Shah \& SA Memon. Wrote the paper: B Mal \& N Memon.

\section{References}

1. Abbas M, Rafi MA, Inayatullah M, Khan MA \& Pavulaan H (2012). Taxonomy and distribution of butterflies (Papilionoidea) of the Skardu region, Pakistan. The Taxonomic Report of the International Lepidoptera survey. 3(9): 1-15.

2. Naz F, Ilyas M, Ashfaque M \& Shahzad A (2010). The genus Junonia (Lepidoptera: nymphalidae) in Pakistan. Sarhad J. Agric. 26(2): 267-270.

3. Robert TJ (2001). Butterflies of Pakistan. Ameena Saiyid, Oxford Univ. Press. 200 p.

4. Hampson GF (1894). The fauna of British India, including Ceylon and Burma. Taylor and Francis. II: 200p

5. Miller LD (1970). Nomenclature of wing veins and cells. Journal of Research in Lepidoptera. 8(2): 37-48.

6. Kaminski LA, Dell'Erba R \& Moreira GRP (2008). Morfologiaexterna dos estágiosimaturos de heliconíneosneotropicais: VI. DionemonetamonetaHübner (Lepidoptera, Nymphalidae, Heliconiinae). RevistaBrasileira de Entomologia. 52:1323.

7. Puri DR (1931). Butterflies of Lahore. Govt. College, Lahore. $61 \mathrm{p}$.

8. Klots AB (1970). "Lepidoptera" Taxonomist's Glossary of Genitalia in Insects. Ed. 2. Copenhagen, Munksgaard. Tuxen S.L (ed.). 115-130.

9. Winter WD (2000). Basic techniques for observing and studying moths and butterflies. Lepidopterists' Society, New Haven, CT. 433Pp.

10. Lesilie GA \& Evans WH (1903). The Butterflies of Chitral. J. Bombay Natural History Soc. 14: 666-678.

11. Bingham CT (1905). Fauna of British India including Ceylon and Burma: Butterflies. Vol. 1. Taylor \& Francis, London. 511 p.

12. Puri DR (1931). Butterflies of Lahore. Govt. College, Lahore. $61 \mathrm{p}$.

13. Ahsan M \& Iqbal J (1975). A contribution to Butterflies of Lahore with the addition of new records. Biologia. 21 (2): 143: 158.

14. Arshad M, Jan GA \&Parveen S (1983). A checklist of Butterflies of NWFP. J. Sci. \& Tech. 7 (1-2): 1-3.

15. Robert TJ (2001). Butterflies of Pakistan. Ameena Saiyid, Oxford Univ. Press. 200 p.

16. Khan MR, Rafi MA \& Nasim M (2004). Diversity of Butterflies from District Muzaffarabad, Azad Kashmir. Pak. J. Biol. Sci. 7 (3): 324-327. 